\title{
Long RNA-Mediated Chromatin Regulation in Fission Yeast and Mammals
}

\author{
Matthew W. Faber and Tommy V. Vo*
}

check for updates

Citation: Faber, M.W.; Vo, T.V. Long RNA-Mediated Chromatin Regulation in Fission Yeast and Mammals. Int. J. Mol. Sci. 2022, 23, 968. https://doi.org/10.3390/ ijms23020968

Academic Editors: Luca Agnelli and Giovanni Malerba

Received: 6 December 2021 Accepted: 13 January 2022 Published: 16 January 2022

Publisher's Note: MDPI stays neutral with regard to jurisdictional claims in published maps and institutional affiliations.

Copyright: (C) 2022 by the authors. Licensee MDPI, Basel, Switzerland. This article is an open access article distributed under the terms and conditions of the Creative Commons Attribution (CC BY) license (https:// creativecommons.org/licenses/by/ $4.0 /)$.
Department of Biochemistry and Molecular Biology, College of Human Medicine, Michigan State University, East Lansing, MI 48824, USA; faberma1@msu.edu

* Correspondence: votommyv@msu.edu

\begin{abstract}
As part of a complex network of genome control, long regulatory RNAs exert significant influences on chromatin dynamics. Understanding how this occurs could illuminate new avenues for disease treatment and lead to new hypotheses that would advance gene regulatory research. Recent studies using the model fission yeast Schizosaccharomyces pombe (S. pombe) and powerful parallel sequencing technologies have provided many insights in this area. This review will give an overview of key findings in S. pombe that relate long RNAs to multiple levels of chromatin regulation: histone modifications, gene neighborhood regulation in cis and higher-order chromosomal ordering. Moreover, we discuss parallels recently found in mammals to help bridge the knowledge gap between the study systems.
\end{abstract}

Keywords: long noncoding RNA; long regulatory RNA; chromatin; gene neighborhood; heterochromatin; higher-order chromosomal architecture; YTH-family protein; S. pombe; mouse; human

\section{Introduction}

From yeast to mammals, eukaryotic genomes can be pervasively transcribed depending on developmental or environmental states. It is estimated that most of the Schizosaccharomyces pombe (fission yeast, S. pombe) and human genomes are transcription-competent [1,2]. Although protein-encoding genes make up a tiny minority of all transcribed genomic units, they have historically garnered the most research attention. However, in light of recent advances in next-generation sequencing and genome editing approaches, there has been increasing engagement in illuminating the functional relevance of genes encoding regulatory RNAs. These include noncoding RNAs and bifunctional RNAs with dual coding and noncoding attributes.

The transcriptional products of noncoding genes can be broadly classified as small noncoding or long noncoding RNAs (lncRNAs). Small noncoding RNAs are less than 200 nucleotides in length and are comprised of major subclasses, including microRNAs (miRNAs), short interfering RNAs (siRNAs), tRNA-derived small RNAs (tsRNAs) and piwi-interacting RNAs (piRNAs). Their roles in transcriptome and chromatin regulation have been extensively reviewed elsewhere and will not be the focus of this review [3-8]. Long RNAs (>200 nucleotides in length) called long noncoding RNAs (lncRNAs) are not believed to be translated into protein. Compared to messenger RNAs (mRNAs), many lncRNAs are poorly conserved in sequence, are less stable and primarily reside within the nucleus. Within yeast, plants and animals, the number of genes encoding lncRNAs vastly outweighs the number of mRNA-encoding genes [9-12], suggesting that either there is substantial non-functional transcriptional noise across eukaryotes or that there remain many functional RNAs still awaiting characterization.

Nevertheless, it has been debated that some annotated lncRNAs might be misannotated and can be translated [13-15]. This idea was supported by ribosome-profiling work showing that many human and mouse lncRNAs can interact with cytoplasmic ribosomes [16,17]. However, it was unclear if the interactions promote the synthesis of 
functional peptides, RNA decay, or other processes. It is certainly possible that some long RNAs may be bifunctional with coding and noncoding functions [18-20]. For example, the first discovered mammalian bifunctional RNA (bifRNA) called Steroid Receptor RNA Activator (SRA) regulates gene expression as an RNA [21] and nuclear receptor complexes as a protein [22]. This review will focus on chromatin regulatory roles of long RNAs, irrespective of whether they might be bona fide lncRNAs or bifRNAs.

In recent years, the combination of facile genetics, molecular biology and biochemistry with high-throughput sequencing approaches has enabled the fission yeast $S$. pombe to become an outstanding model for understanding the regulatory functions of nuclear long RNAs. Excitingly, studies in mammalian mouse and human models are also beginning to reveal similar mechanisms of long RNA action at the chromatin level. Here, we review various chromatin-level modes of long RNA-mediated gene regulation in S. pombe and mammals, with special attention to their similarities. In particular, we will focus on the mechanisms by which long RNAs orchestrate control over epigenetic modifications, transcription termination and higher-order chromatin architectures. Altogether, this review will summarize our latest knowledge on how fission yeast and mammals leverage long RNAs to elicit conserved mechanisms of genome control.

\section{Tools to Identify Long Regulatory RNAs}

Next-generation sequencing (NGS; Illumina, Roche 454) and third-generation sequencing (TGS; PacBio, Nanopore) capabilities have dramatically enabled us to discover long regulatory RNA species. Using strand-specific RNA next-generation sequencing (NGS) to massively produce short sequencing reads is currently the most prominent approach to empirically detect entire RNA repertoires within cells. The short reads are then bioinformatically mapped onto reference transcriptomes, using various open-sourced shortread mapping software [23] to infer any expressed RNA. The mapped RNAs are usually post-characterized bioinformatically or experimentally using RNA probing assays such as Northern blotting. The major advantage of this short-reads sequencing approach is that genomic regions which produce any RNA(s) can be detected with high sensitivity and relatively low background, particularly compared to lower resolution approaches such as tiling arrays. However, it is often challenging to differentiate long RNAs from shorter overlapping ones, which poses a significant problem for small-genome organisms, such as fission yeast, with many overlapping expressed genes. More recently, the emergence of long-read third generation sequencing (TGS), such as PacBio SMRT and Oxford Nanopore, appears to remedy the identification problems faced by short-read sequencing methods $[24,25]$. It is now possible to sequence entire RNAs from $5^{\prime}$ to $3^{\prime}$ ends and directly characterize all present RNA species. The main limitations of TGS methods include the higher error rates, costs and few pre-packaged bioinformatic analysis tools when compared to NGS methods [24].

Post-identification, a range of tools are available to assess the regulatory potential of lncRNA transcripts. Aside from a range of computational tools to predict regulatory functions of lncRNAs [26-28], there are various experimental approaches to more directly test for regulatory potential. Genetically, lncRNAs can be ablated or knocked down to assess the impact on certain phenotypes like gene expressions. These methods include using CRISPR-Cas9, CRISPR-Cas13, or antisense oligonucleotides [29-31]. Genome-wide approaches can also be used to propose regulatory functions via indirect means. Due to the shear abundance of available approaches, Table 1 represents an inexhaustive list of these methods that measure different biophysical properties of lncRNAs including RNA-DNA interactions [32-36], inter-RNA-RNA interactions [37-40], RNA-protein interactions [41-45] and RNA localization [46-48]. More comprehensive reviews elsewhere have been performed on methods that map complex RNA-chromatin interactions [49,50]. Nevertheless, direct genetic and biochemical manipulation of lncRNAs remains the most direct route to elucidating their functions [51]. 
Table 1. Summary of representative methods to detect long noncoding RNA (lncRNA) interactions or localization.

\begin{tabular}{|c|c|c|c|}
\hline Method Full Name & Method Abbrev. & Measurement Type & References \\
\hline $\begin{array}{c}\text { RNA and DNA Split-Pool } \\
\text { Recognition of Interactions by } \\
\text { Tag Extension }\end{array}$ & RD-SPRITE & RNA-DNA interaction & [32] \\
\hline $\begin{array}{l}\text { Chromatin-Associated } \\
\text { RNA sequencing }\end{array}$ & ChAR-seq & RNA-DNA interaction & [33] \\
\hline $\begin{array}{l}\text { RNA-DNA proximity } \\
\text { ligation technique }\end{array}$ & Red-C & RNA-DNA interaction & [34] \\
\hline $\begin{array}{l}\text { Chromatin Isolation by RNA } \\
\text { Purification sequencing }\end{array}$ & ChIRP-seq & RNA-DNA interaction & [35] \\
\hline RNA Antisense Purification & RAP & RNA-DNA interaction & [36] \\
\hline $\begin{array}{l}\text { Ligation of interacting RNA } \\
\text { followed by } \\
\text { high-throughput sequencing }\end{array}$ & LIGR-seq & RNA-RNA interaction & [37] \\
\hline $\begin{array}{l}\text { Cross-linking Ligation and } \\
\text { Sequencing of Hybrids }\end{array}$ & CLASH & RNA-RNA interaction & [38] \\
\hline $\begin{array}{c}\text { RNA In situ } \\
\text { Conformation sequencing }\end{array}$ & RIC-seq & RNA-RNA interaction & [39] \\
\hline $\begin{array}{l}\text { Cross-linking Of Matches RNA } \\
\text { And Deep Sequencing }\end{array}$ & COMRADES & RNA-RNA interaction & [40] \\
\hline RNA Tagging & - & RNA-protein interaction & [41] \\
\hline $\begin{array}{c}\text { RNA } \\
\text { Immunoprecipitation Sequencing }\end{array}$ & RIP-seq & RNA-protein interaction & [43] \\
\hline Yeast three-hybrid & $\mathrm{Y} 3 \mathrm{H}$ & RNA-protein interaction & [45] \\
\hline $\begin{array}{c}\text { Photoactivatable-Ribonucleoside- } \\
\text { Enhanced Crosslinking and } \\
\text { Immunoprecipitation }\end{array}$ & PAR-CLIP & RNA-protein interaction & [44] \\
\hline Proximity Labeling & - & RNA-protein interaction & [42] \\
\hline $\begin{array}{l}\text { APEX2-mediated Proximity } \\
\text { biotinylation of Endogenous RNAs }\end{array}$ & APEX-seq & RNA localization & [46] \\
\hline $\begin{array}{l}\text { Turbo Fluorescence } \\
\text { In Situ Hybridization }\end{array}$ & Turbo FISH & RNA localization & [47] \\
\hline $\begin{array}{l}\text { Sequential Fluorescence } \\
\text { In Situ Hybridization }\end{array}$ & SeqFISH & RNA localization & [48] \\
\hline
\end{tabular}

Long bifRNAs with dual coding and noncoding functions are more complicated to work with because they require dissecting functions of the RNA from the protein that they encode [52]. Genetic inspection of these transcripts often requires introducing synonymous mutations that would ideally preserve coding potential while affecting noncoding functions. However, doing so may still affect translation rates, and thus protein levels, and confuscate biological interpretations [53]. Alternatively, the transcripts can be characterized using the genome-wide approaches described above to interrogate lncRNA functions. Understanding these long RNAs from multiple molecular perspectives are required to determine their regulatory potential.

\section{Long Regulatory RNAs and Their Protein Partners}

It is often that long RNAs, such as lncRNAs and others, may function by regulating transcript-bound protein partners' activities [51]. This can be especially appreciated in the fission yeast $S$. pombe through many studies on the Mmi1 RNA-binding protein, as will be 
our focus below. We will also highlight striking similarities that have only recently been realized between the regulatory functions of Mmi1-targeted transcripts and RNA-targets of YTH Domain Containing 1 (YTHDC1), which is the mammalian homolog of yeast Mmi1.

Mmi1 belongs to the family of conserved YT521-B homology (YTH) domain proteins. Its YTH protein domain, located at the C-terminus of $S$. pombe Mmi1, is essential for directly binding to RNA transcripts [54-56]. Initially, Mmi1 was discovered by Yamamoto and colleagues to genetically interact with meiotic genes to trigger timely RNA degradation and regulate the mitosis-meiosis transition [57]. Mmil directly binds to long transcripts from these loci by recognizing an RNA motif called the Determinant of Selective Removal (DSR). The DSR region is characterized by the consensus hexamer motif U(U/C)AAAC [58]. More recent studies using DNA microarray and NGS approaches discovered that Mmi1 can associate with many other DSR motif-containing long RNAs, including the lncRNAs meiRNA [59], nam [60] and mamRNA [61]. The ability for Mmi1 to interact with RNAs positively correlates with how many closely-spaced repeats of the DSR motif there are within a single transcript [58]. While the Mmi1-RNA associations were initially thought of as unidirectional [57], whereby Mmi1 binding simply leads to transcript elimination, more recent work has shown that the interactions play critical roles in targeted chromatin regulation and nearby-gene control, as discussed in the sections below.

A combination of genetic analyses and protein-centric studies has revealed that transcripts bound by Mmi1 are associated with many additional protein factors. These include the Clr4 methyltransferase that is responsible for the post-translational modification of chromatin with di-methylation of histone H3 lysine-9 (H3K9me2), RNA 3'-end processing and transcription termination (Pab2, Cleavage and Polyadenylation Factor [CPF], Dhp1), RNA 5' binding and splicing (Pir2, Cwf10) and RNA degradation (Erh1, Mt11-Red1 core (MTREC), Ccr4-NOT complex, Rrp6) [60,62-71]. A possible function of these RNAs is to guide Mmi1 with various combinations of other factors to specific genomic loci and to influence gene expression.

In mammals, the Mmi1-homolog YTHDC1 directly binds to the $N^{6}$-methyladenosine $\left(\mathrm{m}^{6} \mathrm{~A}\right)$ post-translational modification of long RNAs [72]. Some of its well-known RNA substrates have known roles in chromatin regulation and protein complex assemblies. These long RNA targets include the lncRNAs metastasis associated lung adenocarcinoma transcript 1 (MALAT1), HOX transcript antisense RNA (HOTAIR) and X-inactive specific transcript (XIST). MALAT1 associates with actively transcribed chromatin regions and positions them near nuclear speckles $[73,74]$. These nuclear bodies are gene expression regulatory factories that contain clusters of RNAs, chromatin remodelers, RNA processing factors and more [75]. A recent study by Wang et al. demonstrated that $\mathrm{m}^{6} \mathrm{~A}$-modified MALAT1 and YTHDC1 are needed for the chromatin-speckles association and gene activation [74]. In contrast, the lncRNA HOTAIR interacts with YTHDC1, including at the $\mathrm{m}^{6} \mathrm{~A}$ modification of HOTAIR residue A783 [76] to localize to chromatin and mediate gene repression. The third mammalian lncRNA XIST has many $\mathrm{m}^{6} \mathrm{~A}$-modifiable sites, with at least 78 residues identified by $\mathrm{m}^{6} \mathrm{~A}$-mapping using $\mathrm{m}^{6} \mathrm{~A}$ iCLIP [77], and interacts with factors such as YTHDC1, SAF-A, SPEN and PRC2 at the inactive X-chromosome [77-80]. There, they promote the assembly of tri-methylated lysine-27 of histone H3 (H3K27me3) and transcriptional repression. Interestingly, recent work has shown that XIST RNA can promote the compartmentalization of specific ribonucleoprotein complexes at chromatin to mediate its silencing functions [81]. Although the exact modes of RNA recognition and binding are different between the homologs $S$. pombe Mmi1 and mammalian YTHDC1, which bind to DSR motifs and $\mathrm{m}^{6} \mathrm{~A}$, respectively [54,55], these conserved proteins can use long RNAs to mediate similar repressive functions. This suggests that the partnership between long RNAs and YTH-domain proteins to regulate chromatin landscapes may be evolutionarily conserved between fission yeast and mammals. 


\section{RNA-Mediated Chromatin Modifications}

Histones within chromatin are subject to post-translational modifications, including methylation, acetylation, ubiquitination, citrullination and phosphorylation. These modifications can act as molecular platforms to recruit gene regulatory factors, such as histone H3 lysine-9 tri-methylation (H3K9me3) recruiting Heterochromatin Protein 1 (HP1) family proteins [82-86]. Additionally, modifications can be epigenetic markers that regulate gene expression in manners that are heritable [3,86-88].

In S. pombe, small and long regulatory RNAs have been linked to targeted histone methylations, particularly $\mathrm{H} 3 \mathrm{~K} 9 \mathrm{me} 2$ and $\mathrm{H} 3 \mathrm{~K} 9 \mathrm{me} 3$. In this yeast and across higher eukaryotes, these modifications are the hallmarks of chromatin domains called heterochromatin $[3,86,87,89,90]$. Heterochromatin regions can have condensed physical structures [91] that serve to be inhibitory to trans-acting factors. The two broad types of heterochromatin that exist are called constitutive and facultative. In S. pombe, constitutive heterochromatin is marked by the presence of $\mathrm{H} 3 \mathrm{~K} 9 \mathrm{me} 2 / 3$ and is predominately nucleated by small interfering RNAs (siRNAs) that derive from repetitive transcripts [3,92]. Conversely, facultative heterochromatin is preferentially enriched for $\mathrm{H} 3 \mathrm{~K} 9 \mathrm{me} 2$ that depends on DNA-binding [93] and RNA-binding factors [62-66,70,94-96].

Recent works in fission yeast have provided mechanistic insights into how long RNAs promote $\mathrm{H} 3 \mathrm{~K} 9 \mathrm{me} 2$ modifications at constitutive and facultative heterochromatin. At pericentromeric constitutive heterochromatin, the existence of distinct regulatory lncRNAs called noncoding RNA associated with Mmi1 (nam) was identified [60]. These transcripts associate with Mmi1 through their DSR motifs. In particular, nam transcripts called nam5/6/7 were found to be produced from pericentromeric $d h$ repeats. Mmi1, the nuclear exosome subunit Rrp6 and the CPF subunit Swd22 target these RNAs to promote H3K9me2 at pericentromeres $[60,66,70]$. It was proposed that transcription termination of these lncRNAs helps to promote H3K9me2 [60], a model supported by prior observations that an essential transcription termination factor, Dhp1, is involved in promoting pericentromeric H3K9me2 [64,96]. Subsequently, it was recently shown that the CPF core subunit Iss1, which Mmi1 can recruit, localizes to the $3^{\prime}$ ends of pericentromeric nam5/6/7 genes [66]. Both CPF and Dhp1 gene-targeting in S. pombe is often needed to mediate transcription termination [97]. To demonstrate the importance of termination on constitutive heterochromatin, it was shown that double mutations in the RNA interference (RNAi) pathway with mutation of either Mmi1 or CPF led to cumulative increases in nam5/6/7 RNA [60] or total ablation of pericentromeric H3K9me2 [66,70], respectively. However, the RNAi pathway appears to play a more prominent role in pericentromeric $\mathrm{H} 3 \mathrm{~K} 9 \mathrm{me} 2$ since mutation of RNAi factors diminish H3K9me2 levels more than mutations in only the Mmi1 pathway $[60,66]$. The Mmi1 pathway might serve as a backup mechanism to ensure the presence of heterochromatic features at the pericentromeres when RNAi is inactive. This might be important to prevent detrimental centromeric instability due to enhanced recombination in the absence of protective heterochromatin [98]. Hence, in addition to small RNAs, IncRNAs also play an important role in promoting the deposition of repressive histone modifications at constitutive heterochromatin in the fission yeast.

In addition to constitutive heterochromatin, Mmi1-targeted RNAs in S. pombe have been shown to be important for promoting $\mathrm{H} 3 \mathrm{~K} 9 \mathrm{me} 2$ at facultative heterochromatin domains called islands [62]. The levels of $\mathrm{H} 3 \mathrm{~K} 9 \mathrm{me} 2$ modifications at these regions vary depending on environmental or developmental conditions and promote the repression of nearby genes $[62,93]$. Furthermore, silencing of the euchromatic ura4 gene can be enforced by the artificial insertion of the gene into a locus near an endogenous facultative island $[66,93,99]$. This is a hallmark Position Effect Variegation (PEV) phenotype characteristic of heterochromatin [100]. In particular, at a subset of islands that comprise meiotic genes, transcription during mitotic growth, which is paradoxically when these genes should be repressed, is required to promote $\mathrm{H} 3 \mathrm{~K} 9 \mathrm{me} 2$ chromatin modifications. The transcription requirement for $\mathrm{H} 3 \mathrm{~K} 9 \mathrm{me} 2$ at these islands was previously demonstrated by the insertion of a premature transcription termination sequence within the promoter of the $s s m 4$ meiotic 
gene that resulted in the loss of $\mathrm{H} 3 \mathrm{~K} 9 \mathrm{me} 2$ at the ssm4 island locus [62]. Transcription of these meiotic genes produces DSR-containing long RNAs that cluster within the nucleus $[94,101]$ and recruit the factors Mmi1, Erh1, MTREC, CPF, Dhp1, Rrp6 and the H3K9 methyltransferase Clr4 (Figure 1a) $[63,64,66,70,94]$. These factors have been implicated in various nuclear processes, including RNA degradation, RNA export, RNA splicing, transcription termination and histone methylation. Recent work has begun to dissect the precise molecular interactions between these distinct factors that ultimately promote the assembly of facultative $\mathrm{H} 3 \mathrm{~K} 9 \mathrm{me} 2$ in S. pombe. The C-terminal YTH domain of Mmi1 can make direct contacts with the DSR motifs of these meiotic long RNAs [54,55]. On the N-terminus of Mmi1 is a domain that makes contact with the highly conserved Erh1 nuclear protein [94] to form the Erh1-Mmi1 complex (EMC) [65]. In vitro, EMC stably exists as a tetrameric complex comprising a dimer of Mmi1-Erh1 dimer (two Mmi1 monomers, two Erh1 monomers). This complex likely binds to DSR-containing meiotic RNAs and modulates the recruitment of other protein factors to prevent untimely meiotic gene expressions $[94,101,102]$. MTREC appears to be an intermediary complex that physically links Mmi1 to Rrp6 and Clr4 [63,103]. This linkage is crucial for promoting H3K9me2 at islands and for the degradation of the meiotic transcripts $[62,68,103]$. In addition, factors involved in transcription termination and RNA $3^{\prime}$-end processing were shown to be essential for island H3K9me2 since genetic mutation of those factors, such as in Dhp1, Swd22 and Ssu72, abolished those chromatin modifications $[64,66,96]$. Recruitment of those factors to the meiotic islands requires Mmi1, suggesting that they may act downstream from or concurrently with Mmi1-RNA binding [66]. Altogether, these island-derived long RNAs promote local chromatin modification by facilitating the recruitment of protein factors that ultimately regulate the chromatin loci from which these RNAs originate.

(a)

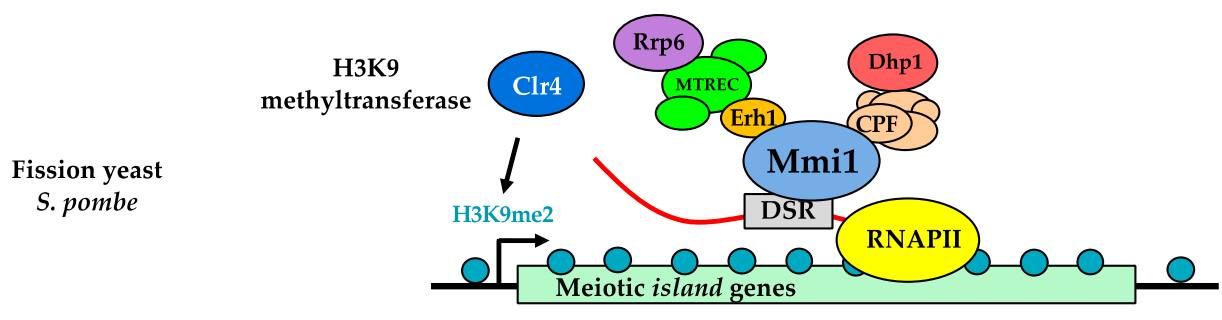

(b)

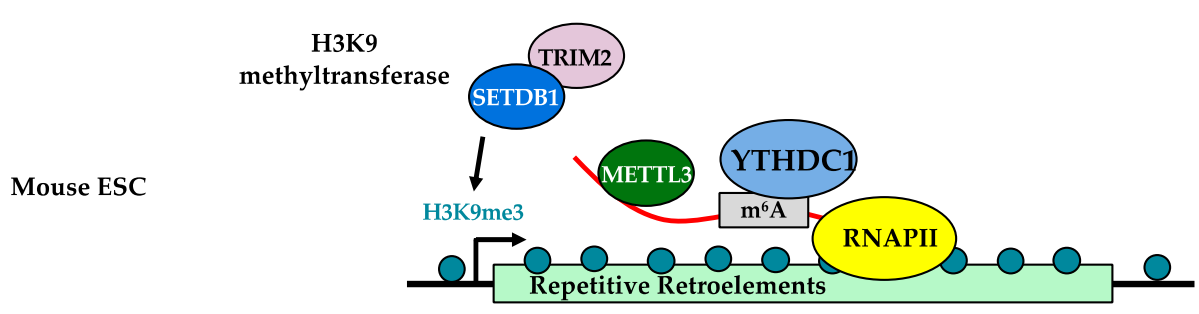

Figure 1. Histone H3 lysine 9 (H3K9) methylation promoted by YTH-family proteins. (a) In S. pombe, Mmi1 binds Determinant of Selective Removal (DSR) sequence motifs of meiotic RNAs derived from islands and engages with additional RNA processing and chromatin modification factors to trigger deposition of H3K9me2. (b) In mouse embryonic stem cells, YTHDC1 binds to certain $\mathrm{m}^{6} \mathrm{~A}$-modified RNAs to promote chromatin-association of $\mathrm{m}^{6} \mathrm{~A}$-writer METTL3. This promotes SETDB/TRIM28-mediated deposition of repressive H3K9me3 modifications.

Recently, work from various groups using mouse embryonic stem cells has shown evidence suggesting that YTHDC1, the mammalian homolog of fission yeast Mmi1, might similarly play important roles in promoting repressive chromatin modifications through long RNA recognition. It was discovered that YTHDC1 binds to $\mathrm{m}^{6} \mathrm{~A}$-marked retrotransposons to promote assembly of SETDB1-mediated H3K9me3 and repression of embryonic 
reprogramming genes, including DUX and MERV [104]. Separately, $\mathrm{Xu}$ et al. found that YTHDC1 binds to chromatin-associated endogenous retroviral (ERV) RNAs that are $\mathrm{m}^{6} \mathrm{~A}-$ modified [105]. In these cases, YTHDC1-RNA binding stabilizes the chromatin association of the $\mathrm{m}^{6} \mathrm{~A}$-writer METTL3, which then recruits the H3K9me3-promoting TRIM28-SETDB1 complex to modify the underlying chromatin domains (Figure $1 \mathrm{~b}$ ). In addition to promoting repressive $\mathrm{H} 3 \mathrm{~K} 9 \mathrm{me} 3$ modifications, a third group showed that YTHDC1 mediates recruitment of Polycomb Complex 2 (PRC2) to chromatin loci [106]. This suggests that YTHDC1 may also help trigger the assembly of repressive H3K27me3, which was recently observed at a reporter gene that expressed $\mathrm{m}^{6} \mathrm{~A}$-modified long RNA [107]. Finally, Quinodoz et al. found that minor and major satellite-derived RNAs cluster at HP1/H3K9me3-rich pericentromeric regions [32]. These RNAs were necessary to recruit HP1 clusters, suggesting that they may act similar to fission yeast nam lncRNAs to promote pericentromeric heterochromatin. In contrast to these findings, another recent study also indicated that YTHDC1 could promote $\mathrm{H} 3 \mathrm{~K} 9 \mathrm{me} 2$ demethylation to help activate gene expression [107]. It is possible that YTHDC1 is multi-functional and assumes different functional identities depending on the target loci. Altogether, recent and emerging studies are beginning to show that mammalian YTHDC1 and fission yeast Mmi1 are important long RNA interactors that facilitate chromatin modifications for proper gene control. These chromatin-level functions add additional complexity to YTH family proteins, which have historically been better characterized as RNA processing factors.

\section{Regulation of Nearby Gene Transcription by Long RNAs}

Virtually all organisms need to address how to coordinate the expression of closelyspaced and sometimes overlapping genes [108]. In these cases, cells must be able to parse distinct genes that may share regulatory features, such as stretches of DNA that could be a promoter of one gene and an open reading frame of another or be influenced by a common transcriptional event. This is a problem that is faced in the human genome, where approximately $25.8 \%$ of coding genes overlap with adjacent genes [109], of which approximately $52.4 \%$ of overlapping pairs consist of tandem genes that are transcribed in the same direction and could potentially experience transcriptional interference [110]. In more gene-dense organisms such as Saccharomyces cerevisiae and S. pombe, where the median intergenic distances are $\sim 366 \mathrm{bp}$ and $\sim 441 \mathrm{bp}$, respectively [111], lncRNAs represent one approach to regulate neighboring genes. For instance, in S. cerevisiae, IncRNAs called upstream-initiating transcripts (UPS) have recently been suggested to regulate transcription of nearby downstream rDNA genes [112]. In S. pombe, three example lncRNAs that have been studied in detail are nam1, rse 1 and prt $[60,63,113]$, which regulate the nearby genes byr2, ste11 and pho1, respectively. Studies on the functions of nam 1 and $r s e 1$ lncRNAs were recently reviewed by Andric and Rougemaille [114] and will not be discussed. Below, we review the current understanding of how the prt lncRNA represses the downstream pho1 coding gene.

Pho1 is a phosphate-responsive secreted acid phosphatase that is involved in phosphate uptake. Its gene expression requires the transcription factor Pho7, which directly binds to the upstream pho1 promoter [115-118]. Pho1 is considered a model nutrient-sensing gene because its expression is inversely correlated with phosphate abundance in the cellular environment $[63,69,119]$. A key question in the field has been how is pho1 expression controlled in response to available phosphate? From the perspective of cellular phosphates, phosphorylation of RNA polymerase II C-terminal domain (CTD) and phosphate-rich inositol pyrophosphates have been shown to affect pho1 expression [119-123]. Interestingly, these factors have been shown to affect a nearby prt IncRNA gene, which is situated immediately upstream of the pho1 coding gene and is transcribed in the same direction as pho1. The prt promoter is within $110 \mathrm{bp}$ upstream of the prt transcribed start site [124]. The prt transcription termination region is located proximal to the promoter of the pho1 gene $[66,69,116]$. While it is well-documented that the prt noncoding gene negatively regu- 
lates pho1 expression $[63,69,124,125]$, recent studies have focused on the precise mechanisms by which the prt lncRNA gene represses expression of the downstream pho1 gene.

Evidence indicates that prt gene transcription promotes pho1 repression. Ablation of the prt promoter or the prt transcribed region completely prevents prt transcription and elevates pho1 expression $[63,69,124]$. Similarly, Yague-Sanz et al. had recently reported that slowing down transcription kinetics by a point mutation within RNA polymerase II (RNAPII) can affect prt transcription and increase pho1 expression [126]. Moreover, extensive studies from Shuman and colleagues have shown that the phosphorylation status of RNAPII impacts the expression of pho1 [120,127,128]. For example, phosphorylation of Ser7 and Ser5 of RNAPII carboxy-terminal domain (CTD) was shown to be required for the repression of pho1 [125]. Subsequently, it was suggested that preventing Ser7 phosphorylation derepresses pho 1 by promoting early CPF-mediated transcription termination of the upstream prt gene [127]. Work from other groups has also shown that direct transcription termination of prt by CPF and Dhp1 $[66,69]$ is likely crucial to enable the Pho7 transcription factor to activate transcription of the downstream pho1 gene [116,117]. Altogether, transcription-related factors at prt appear important for the nearby regulation of $p h o 1$ gene expression in cis.

Increasing evidence suggests that the prt lncRNA has a direct function in regulating its own expression and that of the nearby pho1 gene. The prt transcript has DSR motifs and is bound by Mmi1 protein. Deleting either the DSR motifs or the mmi1 gene leads to prt transcription that continues unabated throughout the pho1 gene body $[63,65,66,69,94]$. Mmi1 directly acts on prt transcript to control downstream pho1 expression because studies using electrophoretic mobility shift assays have confirmed that Mmi1 can only bind prt RNA and not prt ssDNA or dsDNA [124]. These findings, along with the fact that Mmi1 associates with the prt gene locus in chromatin immunoprecipitation assays [65], suggest that the prt lncRNA directly recruits Mmi1 to the vicinity of the underlying chromatin locus. There, Mmi1 recruits CPF to promote early transcription termination of prt to prevent transcriptional readthrough into the pho1 locus, thereby allowing proper pho1 mRNA expression [66,121]. Given that RNAPII CTD phosphorylation statuses also affect prt termination $[120,127,128]$, it is conceivable that the prt lncRNA and the transcriptional process of making the lncRNA both make distinct contributions for modulating the nearby pho1 gene (Figure 2a).

In addition to the Mmi1-binding DSR motifs, deep RNA sequencing recently revealed that the prt long RNA can also contain a cryptic intron [67]. The intron helps link the splicing factor Cwf10 with the $5^{\prime}$ cap-binding protein Pir2 to promote pho1 repression. This newfound protein network also includes RNAi, the Clr3 histone deacetylase and facilitates chromatin transcription (FACT) complex. Hence, the prt lncRNA contains multiple regulatory features. It remains to be seen precisely how prt DSR and cryptic intron signals are coordinated to measure pho1 expression.

In mouse and human, a few lncRNAs (e.g., XIST) have been characterized to regulate the transcription of gene neighborhoods [129]. However, the recently characterized CHD2 adjacent suppressive regulatory RNA (CHASERR) lncRNA appears most similar to yeast prt. It is one of the most conserved lncRNAs across vertebrates and is situated in tandem upstream of the nearby CHD2 gene, which encodes for a DNA helicase $[130,131]$. Similar to the prt-pho1 relationship in fission yeast, Rom et al. found that disruption of CHASERR led to derepression of the downstream CHD2 gene [131,132]. CHASERR-mediated repression of CHD2 likely occurs in cis because exogenous expression of CHASERR in trans was unable to repress $C H D 2$ expression. Still, artificial activation of the lncRNA at its native chromosomal location could repress CHD2. Interestingly, targeting CHASERR using antisense oligonucleotides also led to elevated $\mathrm{CDH} 2$ expression, suggesting that CHASERR IncRNA itself can repress its nearby gene (Figure $2 \mathrm{~b}$ ). Another study predicted that CHASERR might be able to co-transcriptionally base-pair with multiple different nascent RNAs, potentially regulating non-CHD2 genes in trans [133]. Altogether, it is becoming clear that long RNAs 
can have important roles in regulating the transcription of neighboring genes in yeast and mammals.

(a)

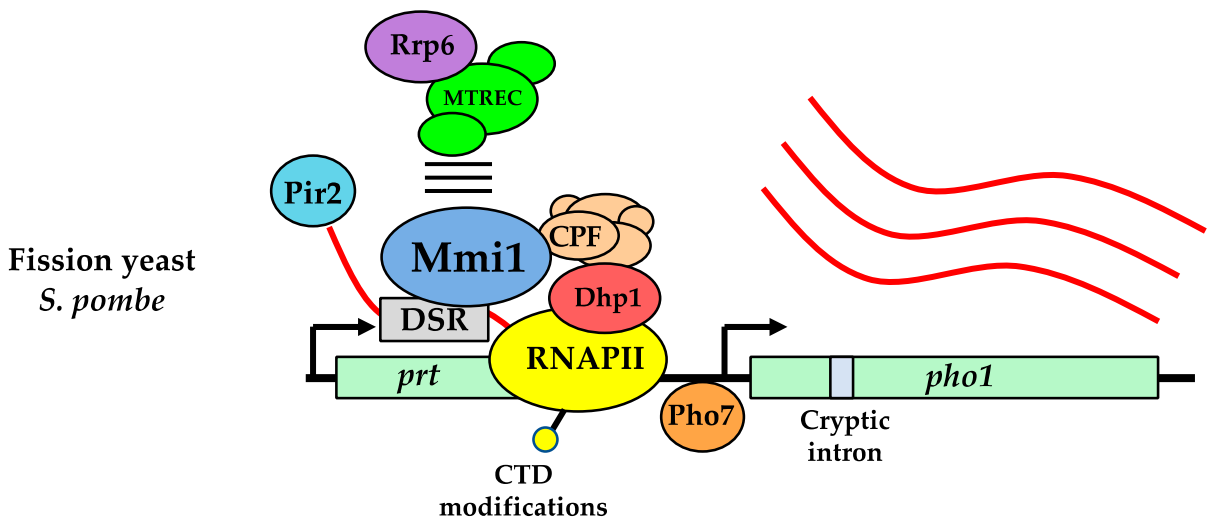

(b)

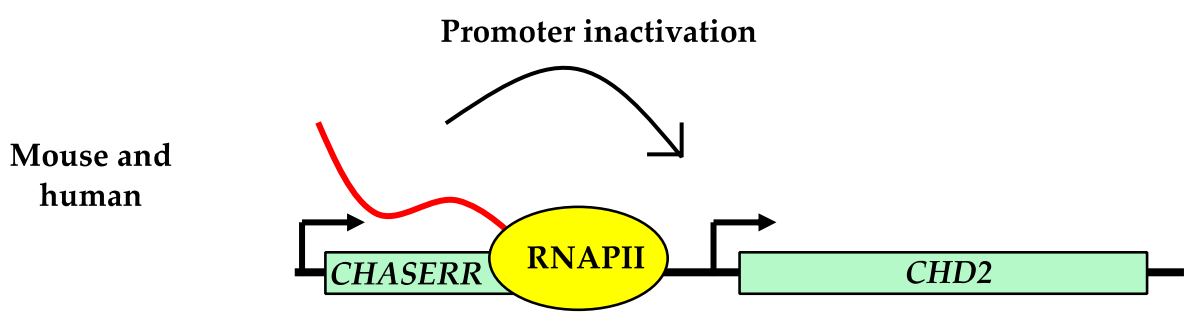

Figure 2. Gene expression control in cis by nearby lncRNAs. (a) In S. pombe, Mmi1 and additional protein factors, that are implicated in RNA processing and transcription regulation, associate with prt gene locus and lncRNA to affect expression of the downstream pho1 gene locus. (b) In mouse and human cells, the lncRNA CHASERR transcriptionally represses the downstream CHD2 gene through mechanisms that are currently unclear.

\section{Higher-Order Chromosomal Structuring by lncRNAs}

Spatiotemporal chromatin regulation is emerging as a topic of great interest due, in part, to the expanding capabilities to determine chromatin architectures and localizations with high resolution $[134,135]$. Recent studies in fission yeast and mammals have suggested that long noncoding RNAs and their protein partners have active roles in this process. A clear example in S. pombe is the meiRNA lncRNA that is transcribed from the sme2 gene [136]. In a similar vein, recent work on so-called architectural RNAs, such as XIST and FIRRE, in mouse or human cell lines provide evidence that mammalian lncRNAs may also play essential roles in higher-order chromosomal structuring [137-141]. The precise roles of these RNAs on higher-order chromatin topology have been a topic of recent interest.

Work from Ding et al. using $S$. pombe has revealed a dependence on lncRNA-centered ribonucleoprotein complexes for one of the most striking examples of chromosomal restructuring: homologous chromosome pairing during meiosis [136,142]. This process begins after two haploid cells fuse their nuclei to reconstitute a diploid cell with two copies of every chromosome. The authors initially noticed from live-cell microscopy that a protein called Mei2, which indirectly associates with the sme2 gene locus through binding the sme2-derived meiRNA [143], only appears as a single focus in diploid cells despite having two homologous alleles of sme2 [136,144]. Subsequently, they found that the Mei2 focus in diploid meiotic cells was a marker for paired homologous sme2 alleles but was not a requirement because disruption of the Mei2-meiRNA interaction did not impede homologous pairing of the sme2 alleles. A recent follow-up study identified additional protein factors whose localization mirrored Mei2. Some, such as Seb1, Pcf11 and Rhn1, were important for sme2 homologous allele pairing [142]. These factors were generically referred to as sme2 RNA-associated protein (Smp) and were enriched for known functional roles in 
RNA polyadenylation or transcription termination (Figure 3a). In addition, the authors found that another chromatin-associated lncRNA called omt3 is required for the proper homologous pairing of chromosome I. The pairing was mediated by the lncRNAs, specific Smps and possibly liquid-liquid phase compartments [142]. These findings suggest that additional chromatin-associated ribonucleoprotein complexes might exist to target other chromosomal regions for proper chromosomal pairing/restructuring during meiosis.

(a)

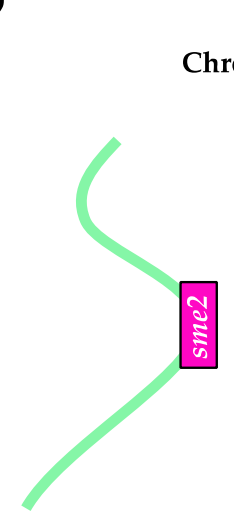

Chr 2
Homologous Chromosome Pairing in S. pombe

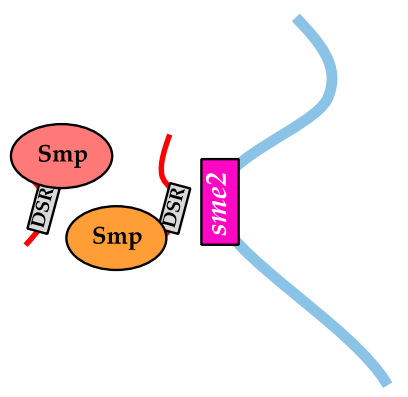

Chr 2 (b)
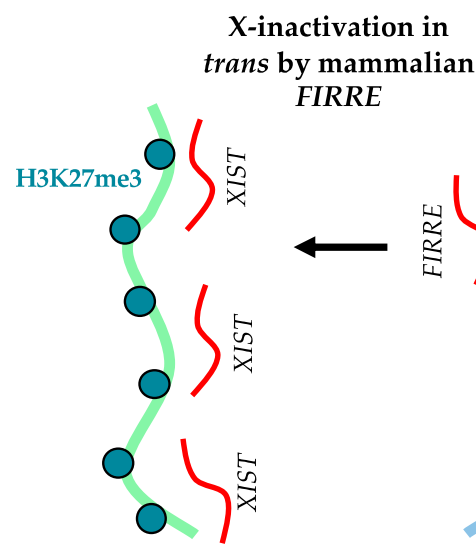

$X i$

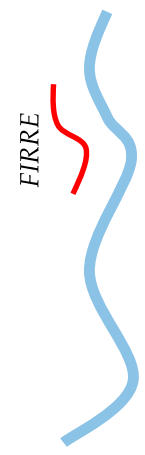

$X a$

Figure 3. Intra-chromosomal regulation by long RNAs. (a) In S. pombe, DSR motif-containing RNAs from homologous chromosomes recruit sme2-assocating proteins (SMPs) to form nuclear clusters that help to bring the homologous chromosomes together. (b) In mammalian cells, the architectural lncRNA FIRRE that is expressed from the active $\mathrm{X}$ chromosome $(\mathrm{X} a)$ promotes $\mathrm{H} 3 \mathrm{~K} 27 \mathrm{me} 3$ and trans inactivation of the $\mathrm{X}$ chromosome $(X i)$.

In mammals, the inactivated $\mathrm{X}$ chromosome $\mathrm{X} i)$ is a prime model for understanding how lncRNAs similarly regulate chromatin. Within female cells that carry two $X$ chromosomes, one is stably inactivated so that $\mathrm{X}$-linked gene dosage is equivalent to $\mathrm{XY}$ male cells, where the sole $X$ chromosome is active $[145,146]$. The XIST lncRNA that is transcribed from $X i$ is critical for inactivation by first nucleating repression at the XIST locus and then spreading along the $X i$ to expand the repression zone $[80,81,147]$. This expansion mechanism is dependent on various repeat motifs present within XIST, as reviewed elsewhere [92]. XIST recruits PRC2 to deposit repressive H3K27me3 marks throughout Xi $[148,149]$. XIST lncRNA also repels binding of chromosomal remodeling proteins, such as cohesin, to enforce $X i$-specific chromosomal structures [138]. In addition to XIST, a more recent study from Fang et al. identified the FIRRE lncRNA, transcribed from the active $\mathrm{X}$ chromosome $(X a)$, as a long-range regulator of the homologous $X i$ [139]. While it minimally affects XISTcoating of the Xi, FIRRE does promote repressive H3K27me3 and localization of the Xi near the nuclear periphery or the nucleolus (Figure 3b). Furthermore, it promotes the binding of another architectural protein called CCCTC-binding factor (CTCF) to the $X i$, with possible implications on Xi chromosomal structure or localization $[139,150]$. More globally, FIRRE has also been suggested to promote H3K27me3 at autosomal chromatin regions [137]. Given the known functional links between heterochromatic maintenance, chromosomal structures and chromosomal localization at the nuclear periphery [84,141,151,152], it will be interesting to further determine the exact roles of lncRNAs, such as FIRRE, within the context of these relationships.

\section{Conclusions}

The fission yeast $S$. pombe has been an important model for understanding how long RNAs shape chromatin landscapes, from the individual locus level to much broader chromosomal regions. The striking conservation of these RNA roles in fission yeast and mammals, representing $\sim 1$ billion years of evolution, strongly suggests that long RNAs 
and their interacting protein partners are crucial mediators between nuclear chromatin and the cellular environment. With major advances in sequencing technologies, the identities and functions of transcriptomes are beginning to emerge in unexpected ways. For example, we now understand that nam lncRNAs in yeast are functional transcripts with significant implications for gene repression. The recent studies highlighted here invite numerous additional questions that could be addressed with currently available technologies. What are the sequenced-based and non-sequenced-based features of long RNAs that confer functional specificity? When do cells employ specific RNA-mediated regulatory mechanisms? With cells often expressing multiple copies of an RNA, how are those copies distributed across the genome for regulatory or non-regulatory purposes?

With the introduction of whole-genome sequencing over two decades ago, it was believed that all genome biology would be solved within a matter of years. Today, that sentiment could not be further from the truth. Very likely, higher quality, higher depth sequencing within the context of different genomic, developmental or environmental conditions will illuminate new strategies by which nature regulates their genomes. This will undoubtedly expand our knowledge on the sophisticated mechanisms by which transcriptional RNA products loop back to regulate the underlying DNA templates.

Author Contributions: M.W.F. and T.V.V. performed literature reviews. M.W.F. and T.V.V. drafted and edited the manuscript. Manuscript preparation was overseen by T.V.V. All authors have read and agreed to the published version of the manuscript.

Funding: The work was supported by startup funds from Michigan State University to T.V.V.

Institutional Review Board Statement: Not applicable.

Informed Consent Statement: Not applicable.

Data Availability Statement: Not applicable.

Acknowledgments: We would like to thank members of the Vo lab for their helpful input on this manuscript.

Conflicts of Interest: The authors declare no conflict of interest.

\section{References}

1. Djebali, S.; Davis, C.A.; Merkel, A.; Dobin, A.; Lassmann, T.; Mortazavi, A.; Tanzer, A.; Lagarde, J.; Lin, W.; Schlesinger, F.; et al. Landscape of transcription in human cells. Nature 2012, 489, 101-108. [CrossRef]

2. Wilhelm, B.T.; Marguerat, S.; Watt, S.; Schubert, F.; Wood, V.; Goodhead, I.; Penkett, C.J.; Rogers, J.; Bahler, J. Dynamic repertoire of a eukaryotic transcriptome surveyed at single-nucleotide resolution. Nature 2008, 453, 1239-1243. [CrossRef]

3. Grewal, S.I.S.; Jia, S. Heterochromatin revisited. Nat. Rev. Genet. 2007, 8, 35-46. [CrossRef]

4. Czech, B.; Hannon, G.J. Small RNA sorting: Matchmaking for Argonautes. Nat. Rev. Genet. 2011, 12, 19-31. [CrossRef]

5. Liu, Q.; Paroo, Z. Biochemical Principles of Small RNA Pathways. Annu. Rev. Biochem. 2010, 79, 295-319. [CrossRef]

6. Rechavi, O.; Lev, I. Principles of Transgenerational Small RNA Inheritance in Caenorhabditis elegans. Curr. Biol. 2017, 27, R720-R730. [CrossRef]

7. Weiser, N.E.; Kim, J.K. Multigenerational Regulation of the Caenorhabditis elegans Chromatin Landscape by Germline Small RNAs. Annu. Rev. Genet. 2019, 53, 289-311. [CrossRef] [PubMed]

8. Bartel, D.P. Metazoan MicroRNAs. Cell 2018, 173, 20-51. [CrossRef] [PubMed]

9. Liu, G.; Mattick, J.; Taft, R.J. A meta-analysis of the genomic and transcriptomic composition of complex life. Cell Cycle 2013, 12, 2061-2072. [CrossRef] [PubMed]

10. Atkinson, S.R.; Marguerat, S.; Bitton, D.A.; Rodríguez-López, M.; Rallis, C.; Lemay, J.-F.; Cotobal, C.; Malecki, M.; Smialowski, P.; Mata, J.; et al. Long noncoding RNA repertoire and targeting by nuclear exosome, cytoplasmic exonuclease, and RNAi in fission yeast. RNA 2018, 24, 1195-1213. [CrossRef]

11. Jiang, S.; Cheng, S.-J.; Ren, L.-C.; Wang, Q.; Kang, Y.-J.; Ding, Y.; Hou, M.; Yang, X.-X.; Lin, Y.; Liang, N.; et al. An expanded landscape of human long noncoding RNA. Nucleic Acids Res. 2019, 47, 7842-7856. [CrossRef] [PubMed]

12. Zhao, L.; Wang, J.; Li, Y.; Song, T.; Wu, Y.; Fang, S.; Bu, D.; Li, H.; Sun, L.; Pei, D.; et al. NONCODEV6: An updated database dedicated to long non-coding RNA annotation in both animals and plants. Nucleic Acids Res. 2021, 49, D165-D171. [CrossRef] [PubMed]

13. Hartford, C.C.R.; Lal, A. When Long Noncoding Becomes Protein Coding. Mol. Cell. Biol. 2020, 40, e00528-19. [CrossRef] 
14. Bánfai, B.; Jia, H.; Khatun, J.; Wood, E.; Risk, B.; Gundling, W.E., Jr.; Kundaje, A.; Gunawardena, H.P.; Yu, Y.; Xie, L.; et al. Long noncoding RNAs are rarely translated in two human cell lines. Genome Res. 2012, 22, 1646-1657. [CrossRef] [PubMed]

15. Andrews, S.J.; Rothnagel, J.A. Emerging evidence for functional peptides encoded by short open reading frames. Nat. Rev. Genet. 2014, 15, 193-204. [CrossRef]

16. Zeng, C.; Fukunaga, T.; Hamada, M. Identification and analysis of ribosome-associated lncRNAs using ribosome profiling data. BMC Genom. 2018, 19, 1-14. [CrossRef]

17. Ji, Z.; Song, R.; Regev, A.; Struhl, K. Many lncRNAs, 5’UTRs, and pseudogenes are translated and some are likely to express functional proteins. eLife 2015, 4, e08890. [CrossRef] [PubMed]

18. Li, J.; Liu, C. Coding or Noncoding, the Converging Concepts of RNAs. Front. Genet. 2019, 10, 496. [CrossRef]

19. Nam, J.-W.; Choi, S.-W.; You, B.-H. Incredible RNA: Dual Functions of Coding and Noncoding. Mol. Cells 2016, 39, 367-374. [CrossRef]

20. Huang, Y.; Wang, J.; Zhao, Y.; Wang, H.; Liu, T.; Li, Y.; Cui, T.; Li, W.; Feng, Y.; Luo, J.; et al. cncRNAdb: A manually curated resource of experimentally supported RNAs with both protein-coding and noncoding function. Nucleic Acids Res. 2021, 49, D65-D70. [CrossRef]

21. Lanz, R.B.; McKenna, N.; Onate, S.A.; Albrecht, U.; Wong, J.; Tsai, S.Y.; Tsai, M.-J.; O’Malley, B.W. A Steroid Receptor Coactivator SRA, Functions as an RNA and Is Present in an SRC-1 Complex. Cell 1999, 97, 17-27. [CrossRef]

22. Chooniedass-Kothari, S.; Emberley, E.; Hamedani, M.; Troup, S.; Wang, X.; Czosnek, A.; Hube, F.; Mutawe, M.; Watson, P.; Leygue, E. The steroid receptor RNA activator is the first functional RNA encoding a protein. FEBS Lett. 2004, 566, 43-47. [CrossRef] [PubMed]

23. Baruzzo, G.; Hayer, K.; Kim, E.J.; Di Camillo, B.; FitzGerald, G.A.; Grant, G.R. Simulation-based comprehensive benchmarking of RNA-seq aligners. Nat. Methods 2017, 14, 135-139. [CrossRef]

24. Amarasinghe, S.L.; Su, S.; Dong, X.; Zappia, L.; Ritchie, M.E.; Gouil, Q. Opportunities and challenges in long-read sequencing data analysis. Genome Biol. 2020, 21, 30. [CrossRef]

25. Weirather, J.L.; de Cesare, M.; Wang, Y.; Piazza, P.; Sebastiano, V.; Wang, X.-J.; Buck, D.; Au, K.F. Comprehensive comparison of Pacific Biosciences and Oxford Nanopore Technologies and their applications to transcriptome analysis. F1000Research 2017, 6 , 100. [CrossRef] [PubMed]

26. Pinkney, H.R.; Wright, B.M.; Diermeier, S.D. The lncRNA Toolkit: Databases and In Silico Tools for lncRNA Analysis. Non-Coding RNA 2020, 6, 49. [CrossRef]

27. Zheng, H.; Talukder, A.; Li, X.; Hu, H. A systematic evaluation of the computational tools for lncRNA identification. Briefings Bioinform. 2021, 22, bbab285. [CrossRef]

28. Gawronski, A.R.; Uhl, M.; Zhang, Y.; Lin, Y.-Y.; Niknafs, Y.S.; Ramnarine, V.R.; Malik, R.; Feng, F.; Chinnaiyan, A.M.; Collins, C.C.; et al. MechRNA: Prediction of lncRNA mechanisms from RNA-RNA and RNA-protein interactions. Bioinformatics 2018, 34, 3101-3110. [CrossRef]

29. Zhen, S.; Li, X. Application of CRISPR-Cas9 for Long Noncoding RNA Genes in Cancer Research. Hum. Gene Ther. 2019, 30, 3-9. [CrossRef] [PubMed]

30. Kannan, S.; Altae-Tran, H.; Jin, X.; Madigan, V.J.; Oshiro, R.; Makarova, K.S.; Koonin, E.V.; Zhang, F. Compact RNA editors with small Cas13 proteins. Nat. Biotechnol. 2021, 39, 1-4. [CrossRef]

31. Merkle, T.; Merz, S.; Reautschnig, P.; Blaha, A.; Li, Q.; Vogel, P.; Wettengel, J.; Li, J.B.; Stafforst, T. Precise RNA editing by recruiting endogenous ADARs with antisense oligonucleotides. Nat. Biotechnol. 2019, 37, 133-138. [CrossRef]

32. Quinodoz, S.A.; Jachowicz, J.W.; Bhat, P.; Ollikainen, N.; Banerjee, A.K.; Goronzy, I.N.; Blanco, M.R.; Chovanec, P.; Chow, A.; Markaki, Y.; et al. RNA promotes the formation of spatial compartments in the nucleus. Cell 2021, 184, 5775-5790.e30. [CrossRef]

33. Bell, J.C.; Jukam, D.; Teran, N.A.; Risca, V.I.; Smith, O.K.; Johnson, W.L.; Skotheim, J.M.; Greenleaf, W.J.; Straight, A.F. Chromatinassociated RNA sequencing (ChAR-seq) maps genome-wide RNA-to-DNA contacts. eLife 2018, 7. [CrossRef] [PubMed]

34. Gavrilov, A.A.; Zharikova, A.A.; Galitsyna, A.A.; Luzhin, A.V.; Rubanova, N.M.; Golov, A.K.; Petrova, N.V.; Logacheva, M.D.; Kantidze, O.L.; Ulianov, S.V.; et al. Studying RNA-DNA interactome by Red-C identifies noncoding RNAs associated with various chromatin types and reveals transcription dynamics. Nucleic Acids Res. 2020, 48, 6699-6714. [CrossRef] [PubMed]

35. Chu, C.; Qu, K.; Zhong, F.; Artandi, S.E.; Chang, H.Y. Genomic Maps of Long Noncoding RNA Occupancy Reveal Principles of RNA-Chromatin Interactions. Mol. Cell 2011, 44, 667-678. [CrossRef]

36. Simon, M.D.; Wang, C.I.; Kharchenko, P.V.; West, J.; Chapman, B.; Alekseyenko, A.A.; Borowsky, M.L.; Kuroda, M.I.; Kingston, R.E. The genomic binding sites of a noncoding RNA. Proc. Natl. Acad. Sci. USA 2011, 108, 20497-20502. [CrossRef]

37. Sharma, E.; Sterne-Weiler, T.; O’Hanlon, D.; Blencowe, B.J. Global Mapping of Human RNA-RNA Interactions. Mol. Cell 2016, 62, 618-626. [CrossRef]

38. Helwak, A.; Kudla, G.; Dudnakova, T.; Tollervey, D. Mapping the Human miRNA Interactome by CLASH Reveals Frequent Noncanonical Binding. Cell 2013, 153, 654-665. [CrossRef]

39. Cai, Z.; Cao, C.; Ji, L.; Ye, R.; Wang, D.; Xia, C.; Wang, S.; Du, Z.; Hu, N.; Yu, X.; et al. RIC-seq for global in situ profiling of RNA-RNA spatial interactions. Nature 2020, 582, 432-437. [CrossRef] [PubMed]

40. Ziv, O.; Gabryelska, M.; Lun, A.T.L.; Gebert, L.F.R.; Sheu-Gruttadauria, J.; Meredith, L.; Liu, Z.-Y.; Kwok, C.K.; Qin, C.-F.; MacRae, I.J.; et al. COMRADES determines in vivo RNA structures and interactions. Nat. Methods 2018, 15, 785-788. [CrossRef] 
41. Lapointe, C.; Wilinski, D.; Saunders, H.A.J.; Wickens, M. Protein-RNA networks revealed through covalent RNA marks. Nat. Methods 2015, 12, 1163-1170. [CrossRef] [PubMed]

42. Qin, W.; Cho, K.F.; Cavanagh, P.E.; Ting, A.Y. Deciphering molecular interactions by proximity labeling. Nat. Methods 2021, 18, 133-143. [CrossRef]

43. Zhao, J.; Ohsumi, T.K.; Kung, J.T.; Ogawa, Y.; Grau, D.J.; Sarma, K.; Song, J.J.; Kingston, R.E.; Borowsky, M.; Lee, J.T. Genome-wide Identification of Polycomb-Associated RNAs by RIP-seq. Mol. Cell 2010, 40, 939-953. [CrossRef]

44. Danan, C.; Manickavel, S.; Hafner, M. PAR-CLIP: A Method for Transcriptome-Wide Identification of RNA Binding Protein Interaction Sites. Methods Mol. Biol. 2022, 2404, 167-188. [CrossRef]

45. Bernstein, D.S.; Buter, N.; Stumpf, C.; Wickens, M. Analyzing mRNA-protein complexes using a yeast three-hybrid system. Methods 2002, 26, 123-141. [CrossRef]

46. Fazal, F.M.; Han, S.; Parker, K.R.; Kaewsapsak, P.; Xu, J.; Boettiger, A.N.; Chang, H.Y.; Ting, A.Y. Atlas of Subcellular RNA Localization Revealed by APEX-Seq. Cell 2019, 178, 473-490.e26. [CrossRef] [PubMed]

47. Shaffer, S.; Wu, M.-T.; Levesque, M.J.; Raj, A. Turbo FISH: A Method for Rapid Single Molecule RNA FISH. PLoS ONE 2013, 8 , e75120. [CrossRef]

48. Shah, S.; Takei, Y.; Zhou, W.; Lubeck, E.; Yun, J.; Eng, C.-H.L.; Koulena, N.; Cronin, C.; Karp, C.; Liaw, E.J.; et al. Dynamics and Spatial Genomics of the Nascent Transcriptome by Intron seqFISH. Cell 2018, 174, 363-376.e16. [CrossRef] [PubMed]

49. Kato, M.; Carninci, P. Genome-Wide Technologies to Study RNA-Chromatin Interactions. Non-Coding RNA 2020, 6, 20. [CrossRef]

50. Mishra, K.; Kanduri, C. Understanding Long Noncoding RNA and Chromatin Interactions: What We Know So Far. Non-Coding RNA 2019, 5, 54. [CrossRef]

51. Bassett, A.R.; Akhtar, A.; Barlow, D.P.; Bird, A.; Brockdorff, N.; Duboule, D.; Ephrussi, A.; Ferguson-Smith, A.; Gingeras, T.R.; Haerty, W.; et al. Considerations when investigating lncRNA function in vivo. eLife 2014, 3, e03058. [CrossRef] [PubMed]

52. Dinger, M.E.; Pang, K.C.; Mercer, T.R.; Mattick, J.S. Differentiating Protein-Coding and Noncoding RNA: Challenges and Ambiguities. PLOS Comput. Biol. 2008, 4, e1000176. [CrossRef]

53. Liu, Y.; Yang, Q.; Zhao, F. Synonymous but Not Silent: The Codon Usage Code for Gene Expression and Protein Folding. Annu. Rev. Biochem. 2021, 90, 375-401. [CrossRef]

54. Wang, C.; Zhu, Y.; Bao, H.; Jiang, Y.; Xu, C.; Wu, J.; Shi, Y. A novel RNA-binding mode of the YTH domain reveals the mechanism for recognition of determinant of selective removal by Mmi1. Nucleic Acids Res. 2016, 44, 969-982. [CrossRef] [PubMed]

55. Wu, B.; Xu, J.; Su, S.; Liu, H.; Gan, J.; Ma, J. Structural insights into the specific recognition of DSR by the YTH domain containing protein Mmi1. Biochem. Biophys. Res. Commun. 2017, 491, 310-316. [CrossRef]

56. Stowell, J.A.W.; Wagstaff, J.L.; Hill, C.H.; Yu, M.; McLaughlin, S.H.; Freund, S.M.V.; Passmore, L.A. A low-complexity region in the YTH domain protein Mmi1 enhances RNA binding. J. Biol. Chem. 2018, 293, 9210-9222. [CrossRef]

57. Harigaya, Y.; Tanaka, H.; Yamanaka, S.; Tanaka, K.; Watanabe, Y.; Tsutsumi, C.; Chikashige, Y.; Hiraoka, Y.; Yamashita, A.; Yamamoto, M. Selective elimination of messenger RNA prevents an incidence of untimely meiosis. Nature 2006, 442, 45-50. [CrossRef] [PubMed]

58. Yamashita, A.; Shichino, Y.; Tanaka, H.; Hiriart, E.; Touat-Todeschini, L.; Vavasseur, A.; Ding, D.-Q.; Hiraoka, Y.; Verdel, A.; Yamamoto, M. Hexanucleotide motifs mediate recruitment of the RNA elimination machinery to silent meiotic genes. Open Biol. 2012, 2, 120014. [CrossRef]

59. Yamashita, A. meiRNA, A Polyvalent Player in Fission Yeast Meiosis. Non-Coding RNA 2019, 5, 45. [CrossRef]

60. Touat-Todeschini, L.; Shichino, Y.; Dangin, M.; Thierry-Mieg, N.; Gilquin, B.; Hiriart, E.; Sachidanandam, R.; Lambert, E.; Brettschneider, J.; Reuter, M.; et al. Selective termination of lnc RNA transcription promotes heterochromatin silencing and cell differentiation. EMBO J. 2017, 36, 2626-2641. [CrossRef] [PubMed]

61. Andric, V.; Nevers, A.; Hazra, D.; Auxilien, S.; Menant, A.; Graille, M.; Palancade, B.; Rougemaille, M. A scaffold lncRNA shapes the mitosis to meiosis switch. Nat. Commun. 2021, 12, 770. [CrossRef]

62. Zofall, M.; Yamanaka, S.; Reyes-Turcu, F.E.; Zhang, K.; Rubin, C.; Grewal, S.I.S. RNA Elimination Machinery Targeting Meiotic mRNAs Promotes Facultative Heterochromatin Formation. Science 2012, 335, 96-100. [CrossRef]

63. Lee, N.N.; Chalamcharla, V.R.; Reyes-Turcu, F.; Mehta, S.; Zofall, M.; Balachandran, V.; Dhakshnamoorthy, J.; Taneja, N.; Yamanaka, S.; Zhou, M.; et al. Mtr4-like Protein Coordinates Nuclear RNA Processing for Heterochromatin Assembly and for Telomere Maintenance. Cell 2013, 155, 1061-1074. [CrossRef] [PubMed]

64. Chalamcharla, V.R.; Folco, H.D.; Dhakshnamoorthy, J.; Grewal, S.I.S. Conserved factor Dhp1/Rat1/Xrn2 triggers premature transcription termination and nucleates heterochromatin to promote gene silencing. Proc. Natl. Acad. Sci. USA 2015, 112, 15548-15555. [CrossRef] [PubMed]

65. Sugiyama, T.; Thillainadesan, G.; Chalamcharla, V.R.; Meng, Z.; Balachandran, V.; Dhakshnamoorthy, J.; Zhou, M.; Grewal, S.I. Enhancer of Rudimentary Cooperates with Conserved RNA-Processing Factors to Promote Meiotic mRNA Decay and Facultative Heterochromatin Assembly. Mol. Cell 2016, 61, 747-759. [CrossRef] [PubMed]

66. Vo, T.V.; Dhakshnamoorthy, J.; Larkin, M.; Zofall, M.; Thillainadesan, G.; Balachandran, V.; Holla, S.; Wheeler, D.; Grewal, S.I. CPF Recruitment to Non-canonical Transcription Termination Sites Triggers Heterochromatin Assembly and Gene Silencing. Cell Rep. 2019, 28, 267-281.e5. [CrossRef] [PubMed]

67. Thillainadesan, G.; Xiao, H.; Holla, S.; Dhakshnamoorthy, J.; Jenkins, L.M.M.; Wheeler, D.; Grewal, S.I.S. Conserved protein Pir2ARS2 mediates gene repression through cryptic introns in lncRNAs. Nat. Commun. 2020, 11, 2412. [CrossRef] 
68. Sugiyama, T.; Sugioka-Sugiyama, R. Red1 promotes the elimination of meiosis-specific mRNAs in vegetatively growing fission yeast. EMBO J. 2011, 30, 1027-1039. [CrossRef]

69. Shah, S.; Wittmann, S.; Kilchert, C.; Vasiljeva, L. IncRNA recruits RNAi and the exosome to dynamically regulate pho1 expression in response to phosphate levels in fission yeast. Genes Dev. 2014, 28, 231-244. [CrossRef]

70. Lee, S.Y.; Hung, S.; Esnault, C.; Pathak, R.; Johnson, K.R.; Bankole, O.; Yamashita, A.; Zhang, H.; Levin, H.L. Dense Transposon Integration Reveals Essential Cleavage and Polyadenylation Factors Promote Heterochromatin Formation. Cell Rep. 2020, 30, 2686-2698.e8. [CrossRef]

71. Kilchert, C.; Hester, S.; Castello, A.; Mohammed, S.; Vasiljeva, L. Comparative Poly(A)+ RNA Interactome Capture of RNA Surveillance Mutants. Methods Mol. Biol. 2020, 2062, 255-276. [CrossRef]

72. Xu, C.; Wang, X.; Liu, K.; Roundtree, I.A.; Tempel, W.; Li, Y.; Lu, Z.; He, C.; Min, J. Structural basis for selective binding of $\mathrm{m}^{6} \mathrm{~A}$ RNA by the YTHDC1 YTH domain. Nat. Chem. Biol. 2014, 10, 927-929. [CrossRef]

73. West, J.A.; Davis, C.P.; Sunwoo, H.; Simon, M.D.; Sadreyev, R.I.; Wang, P.I.; Tolstorukov, M.Y.; Kingston, R.E. The Long Noncoding RNAs NEAT1 and MALAT1 Bind Active Chromatin Sites. Mol. Cell 2014, 55, 791-802. [CrossRef]

74. Wang, X.; Liu, C.; Zhang, S.; Yan, H.; Zhang, L.; Jiang, A.; Liu, Y.; Feng, Y.; Li, D.; Guo, Y.; et al. N6-methyladenosine modification of MALAT1 promotes metastasis via reshaping nuclear speckles. Dev. Cell 2021, 56, 702-715.e8. [CrossRef] [PubMed]

75. Saitoh, N.; Spahr, C.S.; Patterson, S.D.; Bubulya, P.; Neuwald, A.F.; Spector, D.L. Proteomic Analysis of Interchromatin Granule Clusters. Mol. Biol. Cell 2004, 15, 3876-3890. [CrossRef]

76. Porman, A.M.; Roberts, J.T.; Duncan, E.D.; Chrupcala, M.L.; Levine, A.A.; Kennedy, M.A.; Williams, M.M.; Richer, J.K.; Johnson, A.M. A single N6-methyladenosine site in lncRNA HOTAIR regulates its function in breast cancer cells. bioRxiv 2021. [CrossRef]

77. Patil, D.P.; Chen, C.K.; Pickering, B.F.; Chow, A.; Jackson, C.; Guttman, M.; Jaffrey, S.R. m6A RNA methylation promotes XIST-mediated transcriptional repression. Nature 2016, 537, 369-373. [CrossRef] [PubMed]

78. Hasegawa, Y.; Brockdorff, N.; Kawano, S.; Tsutui, K.; Tsutui, K.; Nakagawa, S. The Matrix Protein hnRNP U Is Required for Chromosomal Localization of Xist RNA. Dev. Cell 2010, 19, 469-476. [CrossRef] [PubMed]

79. Colognori, D.; Sunwoo, H.; Kriz, A.J.; Wang, C.-Y.; Lee, J.T. Xist Deletional Analysis Reveals an Interdependency between Xist RNA and Polycomb Complexes for Spreading along the Inactive X. Mol. Cell 2019, 74, 101-117.e10. [CrossRef]

80. Rodermund, L.; Coker, H.; Oldenkamp, R.; Wei, G.; Bowness, J.; Rajkumar, B.; Nesterova, T.; Pinto, D.M.S.; Schermelleh, L.; Brockdorff, N. Time-resolved structured illumination microscopy reveals key principles of Xist RNA spreading. Science 2021, 372, 1167-1182. [CrossRef]

81. Markaki, Y.; Chong, J.G.; Wang, Y.; Jacobson, E.C.; Luong, C.; Tan, S.Y.; Maestrini, D.; Banerjee, A.K.; Mistry, B.A.; Dror, I. Xist nucleates local protein gradients to propagate silencing across the $X$ chromosome. Cell 2021, 184, 6174-6192. [CrossRef]

82. Sugiyama, T.; Cam, H.P.; Sugiyama, R.; Noma, K.-I.; Zofall, M.; Kobayashi, R.; Grewal, S.I. SHREC, an Effector Complex for Heterochromatic Transcriptional Silencing. Cell 2007, 128, 491-504. [CrossRef]

83. Motamedi, M.R.; Hong, E.-J.E.; Li, X.; Gerber, S.; Denison, C.; Gygi, S.; Moazed, D. HP1 Proteins Form Distinct Complexes and Mediate Heterochromatic Gene Silencing by Nonoverlapping Mechanisms. Mol. Cell 2008, 32, 778-790. [CrossRef]

84. Holla, S.; Dhakshnamoorthy, J.; Folco, H.D.; Balachandran, V.; Xiao, H.; Sun, L.-L.; Wheeler, D.; Zofall, M.; Grewal, S.I. Positioning Heterochromatin at the Nuclear Periphery Suppresses Histone Turnover to Promote Epigenetic Inheritance. Cell 2020, 180, 150-164.e15. [CrossRef] [PubMed]

85. Al-Sady, B.; Madhani, H.; Narlikar, G.J. Division of Labor between the Chromodomains of HP1 and Suv39 Methylase Enables Coordination of Heterochromatin Spread. Mol. Cell 2013, 51, 80-91. [CrossRef]

86. Allshire, R.; Madhani, H.D. Ten principles of heterochromatin formation and function. Nat. Rev. Mol. Cell Biol. 2018, 19, 229-244. [CrossRef] [PubMed]

87. Holoch, D.; Moazed, D. RNA-mediated epigenetic regulation of gene expression. Nat. Rev. Genet. 2015, 16, 71-84. [CrossRef]

88. Taneja, N.; Grewal, S. Shushing histone turnover: It's FUN protecting epigenome-genome. Cell Cycle 2017, 16, 1731-1732. [CrossRef] [PubMed]

89. Nicetto, D.; Donahue, G.; Jain, T.; Peng, T.; Sidoli, S.; Sheng, L.; Montavon, T.; Becker, J.S.; Grindheim, J.M.; Blahnik, K.; et al. H3K9me3-heterochromatin loss at protein-coding genes enables developmental lineage specification. Science 2019, 363, $294-297$. [CrossRef]

90. Zhang, K.; Mosch, K.; Fischle, W.; Grewal, S. Roles of the Clr4 methyltransferase complex in nucleation, spreading and maintenance of heterochromatin. Nat. Struct. Mol. Biol. 2008, 15, 381-388. [CrossRef]

91. Becker, J.; McCarthy, R.L.; Sidoli, S.; Donahue, G.; Kaeding, K.; He, Z.; Lin, S.; Garcia, B.A.; Zaret, K.S. Genomic and Proteomic Resolution of Heterochromatin and Its Restriction of Alternate Fate Genes. Mol. Cell 2017, 68, 1023-1037.e15. [CrossRef]

92. Trigiante, G.; Ruiz, N.B.; Cerase, A. Emerging Roles of Repetitive and Repeat-Containing RNA in Nuclear and Chromatin Organization and Gene Expression. Front. Cell Dev. Biol. 2021, 9, 735527. [CrossRef]

93. Zofall, M.; Smith, D.R.; Mizuguchi, T.; Dhakshnamoorthy, J.; Grewal, S.I. Taz1-Shelterin Promotes Facultative Heterochromatin Assembly at Chromosome-Internal Sites Containing Late Replication Origins. Mol. Cell 2016, 62, 862-874. [CrossRef] [PubMed]

94. Xie, G.; Vo, T.V.; Thillainadesan, G.; Holla, S.; Zhang, B.; Jiang, Y.; Lv, M.; Xu, Z.; Wang, C.; Balachandran, V.; et al. A conserved dimer interface connects ERH and YTH family proteins to promote gene silencing. Nat. Commun. 2019, 10, 251. [CrossRef]

95. Yamanaka, S.; Mehta, S.; Reyes-Turcu, F.E.; Zhuang, F.; Fuchs, R.T.; Rong, Y.; Robb, G.B.; Grewal, S.I.S. RNAi triggered by specialized machinery silences developmental genes and retrotransposons. Nature 2013, 493, 557-560. [CrossRef] 
96. Tucker, J.F.; Ohle, C.; Schermann, G.; Bendrin, K.; Zhang, W.; Fischer, T.; Zhang, K. A Novel Epigenetic Silencing Pathway Involving the Highly Conserved 5'-3' Exoribonuclease Dhp1/Rat1/Xrn2 in Schizosaccharomyces pombe. PLoS Genet. 2016, 12, e1005873. [CrossRef]

97. LaRochelle, M.; Robert, M.-A.; Hébert, J.-N.; Liu, X.; Matteau, D.; Rodrigue, S.; Tian, B.; Jacques, P.; Bachand, F. Common mechanism of transcription termination at coding and noncoding RNA genes in fission yeast. Nat. Commun. 2018, 9, 4364 [CrossRef]

98. Hannon, G.J. RNAi: A Guide to Gene Silencing; Cold Spring Harbor Laboratory Press: Cold Spring Harbor, NY, USA, 2003.

99. Sadeghi, L.; Prasad, P.; Ekwall, K.; Cohen, A.; Svensson, J.P. The P af1 complex factors L eo1 and P af1 promote local histone turnover to modulate chromatin states in fission yeast. EMBO Rep. 2015, 16, 1673-1687. [CrossRef] [PubMed]

100. Janssen, A.; Colmenares, S.U.; Karpen, G.H. Heterochromatin: Guardian of the Genome. Annu. Rev. Cell Dev. Biol. 2018, 34, 265-288. [CrossRef]

101. Shichino, Y.; Otsubo, Y.; Kimori, Y.; Yamamoto, M.; Yamashita, A. YTH-RNA-binding protein prevents deleterious expression of meiotic proteins by tethering their mRNAs to nuclear foci. eLife 2018, 7, e32155. [CrossRef] [PubMed]

102. Hazra, D.; Andrić, V.; Palancade, B.; Rougemaille, M.; Graille, M. Formation of S. pombe Erh1 homodimer mediates gametogenic gene silencing and meiosis progression. Sci. Rep. 2020, 10, 1034. [CrossRef]

103. Shichino, Y.; Otsubo, Y.; Yamamoto, M.; Yamashita, A. Meiotic gene silencing complex MTREC/NURS recruits the nuclear exosome to YTH-RNA-binding protein Mmi1. PLoS Genet. 2020, 16, e1008598. [CrossRef] [PubMed]

104. Liu, J.; Gao, M.; He, J.; Wu, K.; Lin, S.; Jin, L.; Chen, Y.; Liu, H.; Shi, J.; Wang, X.; et al. The RNA m6A reader YTHDC1 silences retrotransposons and guards ES cell identity. Nature 2021, 591, 322-326. [CrossRef]

105. Xu, W.; Li, J.; He, C.; Wen, J.; Ma, H.; Rong, B.; Diao, J.; Wang, L.; Wang, J.; Wu, F.; et al. METTL3 regulates heterochromatin in mouse embryonic stem cells. Nature 2021, 591, 317-321. [CrossRef]

106. Liu, J.; Dou, X.; Chen, C.; Chen, C.; Liu, C.; Xu, M.M.; Zhao, S.; Shen, B.; Gao, Y.; Han, D.; et al. N 6 -methyladenosine of chromosome-associated regulatory RNA regulates chromatin state and transcription. Science 2020, 367, 580-586. [CrossRef]

107. Li, Y.; Xia, L.; Tan, K.; Ye, X.; Zuo, Z.; Li, M.; Xiao, R.; Wang, Z.; Liu, X.; Deng, M.; et al. N6-Methyladenosine co-transcriptionally directs the demethylation of histone H3K9me2. Nat. Genet. 2020, 52, 870-877. [CrossRef]

108. Berretta, J.; Morillon, A. Pervasive transcription constitutes a new level of eukaryotic genome regulation. EMBO Rep. 2009, 10, 973-982. [CrossRef] [PubMed]

109. Chen, C.-H.; Pan, C.-Y.; Lin, W.-C. Overlapping protein-coding genes in human genome and their coincidental expression in tissues. Sci. Rep. 2019, 9, 13377. [CrossRef]

110. Nissani, N.; Ulitsky, I. Unique features of transcription termination and initiation at closely spaced tandem human genes. bioRxiv 2021. [CrossRef]

111. Lantermann, A.B.; Straub, T.; Strålfors, A.; Yuan, G.-C.; Ekwall, K.; Korber, P. Schizosaccharomyces pombe genome-wide nucleosome mapping reveals positioning mechanisms distinct from those of Saccharomyces cerevisiae. Nat. Struct. Mol. Biol. 2010, 17, 251-257. [CrossRef] [PubMed]

112. Lesage, E.; Perez-Fernandez, J.; Queille, S.; Dez, C.; Gadal, O.; Kwapisz, M. Non-Coding, RNAPII-Dependent Transcription at the Promoters of rRNA Genes Regulates Their Chromatin State in S. cerevisiae. Non-Coding RNA 2021, 7, 41. [CrossRef]

113. Fauquenoy, S.; Migeot, V.; Finet, O.; Yague-Sanz, C.; Khorosjutina, O.; Ekwall, K.; Hermand, D. Repression of Cell Differentiation by a cis-Acting lincRNA in Fission Yeast. Curr. Biol. 2018, 28, 383-391.e3. [CrossRef] [PubMed]

114. Andric, V.; Rougemaille, M. Long Non-Coding RNAs in the Control of Gametogenesis: Lessons from Fission Yeast. Non-Coding RNA 2021, 7, 34. [CrossRef]

115. Carter-O'Connell, I.; Peel, M.T.; Wykoff, D.D.; O'Shea, E.K. Genome-Wide Characterization of the Phosphate Starvation Response in Schizosaccharomyces pombe. BMC Genom. 2012, 13, 697. [CrossRef] [PubMed]

116. Schwer, B.; Sanchez, A.; Garg, A.; Chatterjee, D.; Shuman, S. Defining the DNA Binding Site Recognized by the Fission Yeast Zn 2 Cys 6 Transcription Factor Pho7 and Its Role in Phosphate Homeostasis. mBio 2017, 8, e01218-17. [CrossRef] [PubMed]

117. Garg, A.; Goldgur, Y.; Schwer, B.; Shuman, S. Distinctive structural basis for DNA recognition by the fission yeast Zn2Cys6 transcription factor Pho7 and its role in phosphate homeostasis. Nucleic Acids Res. 2018, 46, 11262-11273. [CrossRef] [PubMed]

118. Garg, A.; Goldgur, Y.; Sanchez, A.; Schwer, B.; Shuman, S. Structure of Fission Yeast Transcription Factor Pho7 Bound to pho1 Promoter DNA and Effect of Pho7 Mutations on DNA Binding and Phosphate Homeostasis. Mol. Cell. Biol. 2019, 39, e00132-19. [CrossRef] [PubMed]

119. Henry, T.C.; Power, J.E.; Kerwin, C.L.; Mohammed, A.; Weissman, J.S.; Cameron, D.M.; Wykoff, D.D. Systematic Screen of Schizosaccharomyces pombe Deletion Collection Uncovers Parallel Evolution of the Phosphate Signal Transduction Pathway in Yeasts. Eukaryot. Cell 2011, 10, 198-206. [CrossRef]

120. Schwer, B.; Bitton, D.A.; Sanchez, A.M.; Bähler, J.; Shuman, S. Individual letters of the RNA polymerase II CTD code govern distinct gene expression programs in fission yeast. Proc. Natl. Acad. Sci. USA 2014, 111, 4185-4190. [CrossRef]

121. Sanchez, A.; Garg, A.; Shuman, S.; Schwer, B. Inositol pyrophosphates impact phosphate homeostasis via modulation of RNA $3^{\prime}$ processing and transcription termination. Nucleic Acids Res. 2019, 47, 8452-8469. [CrossRef]

122. Garg, A.; Shuman, S.; Schwer, B. A genetic screen for suppressors of hyper-repression of the fission yeast PHO regulon by Pol2 CTD mutation T4A implicates inositol 1-pyrophosphates as agonists of precocious lncRNA transcription termination. Nucleic Acids Res. 2020, 48, 10739-10752. [CrossRef] [PubMed] 
123. Estill, M.; Kerwin-Iosue, C.L.; Wykoff, D.D. Dissection of the PHO pathway in Schizosaccharomyces pombe using epistasis and the alternate repressor adenine. Curr. Genet. 2015, 61, 175-183. [CrossRef] [PubMed]

124. Chatterjee, D.; Sanchez, A.; Goldgur, Y.; Shuman, S.; Schwer, B. Transcription of lncRNA prt, clustered prt RNA sites for Mmi1 binding, and RNA polymerase II CTD phospho-sites govern the repression of pho1 gene expression under phosphate-replete conditions in fission yeast. RNA 2016, 22, 1011-1025. [CrossRef]

125. Schwer, B.; Sanchez, A.M.; Shuman, S. RNA polymerase II CTD phospho-sites Ser5 and Ser7 govern phosphate homeostasis in fission yeast. RNA 2015, 21, 1770-1780. [CrossRef] [PubMed]

126. Yague-Sanz, C.; Vanrobaeys, Y.; Fernandez, R.; Duval, M.; LaRochelle, M.; Beaudoin, J.; Berro, J.; Labbé, S.; Jacques, P.; Bachand, F. Nutrient-dependent control of RNA polymerase II elongation rate regulates specific gene expression programs by alternative polyadenylation. Genes Dev. 2020, 34, 883-897. [CrossRef]

127. Sanchez, A.; Shuman, S.; Schwer, B. RNA polymerase II CTD interactome with $3^{\prime}$ processing and termination factors in fission yeast and its impact on phosphate homeostasis. Proc. Natl. Acad. Sci. USA 2018, 115, E10652-E10661. [CrossRef]

128. Garg, A.; Sanchez, A.M.; Schwer, B.; Shuman, S. Transcriptional profiling of fission yeast RNA polymerase II CTD mutants. RNA 2021, 27, 560-570. [CrossRef]

129. Van Bemmel, J.G.; Galupa, R.; Gard, C.; Servant, N.; Picard, C.; Davies, J.; Szempruch, A.J.; Zhan, Y.; Żylicz, J.J.; Nora, E.P.; et al The bipartite TAD organization of the X-inactivation center ensures opposing developmental regulation of Tsix and Xist. Nat. Genet. 2019, 51, 1024-1034. [CrossRef]

130. Ulitsky, I.; Shkumatava, A.; Jan, C.H.; Sive, H.; Bartel, D.P. Conserved Function of lincRNAs in Vertebrate Embryonic Development despite Rapid Sequence Evolution. Cell 2011, 147, 1537-1550. [CrossRef]

131. Rom, A.; Melamed, L.; Gil, N.; Goldrich, M.J.; Kadir, R.; Golan, M.; Biton, I.; Perry, R.B.-T.; Ulitsky, I. Regulation of CHD2 expression by the Chaserr long noncoding RNA gene is essential for viability. Nat. Commun. 2019, 10, 5092. [CrossRef]

132. Engreitz, J.M.; Haines, J.E.; Perez, E.; Munson, G.; Chen, J.; Kane, M.; McDonel, P.E.; Guttman, M.; Lander, E.S. Local regulation of gene expression by lncRNA promoters, transcription and splicing. Nature 2016, 539, 452-455. [CrossRef]

133. Antonov, I.; Medvedeva, Y. Direct Interactions with Nascent Transcripts Is Potentially a Common Targeting Mechanism of Long Non-Coding RNAs. Genes 2020, 11, 1483. [CrossRef]

134. Xu, J.; Ma, H.; Ma, H.; Jiang, W.; Mela, C.A.; Duan, M.; Zhao, S.; Gao, C.; Hahm, E.-R.; Lardo, S.M.; et al. Super-resolution imaging reveals the evolution of higher-order chromatin folding in early carcinogenesis. Nat. Commun. 2020, 11, 1899. [CrossRef]

135. Ghosh, R.P.; Meyer, B.J. Spatial Organization of Chromatin: Emergence of Chromatin Structure During Development. Annu. Rev. Cell Dev. Biol. 2021, 37, 199-232. [CrossRef] [PubMed]

136. Ding, D.-Q.; Okamasa, K.; Yamane, M.; Tsutsumi, C.; Haraguchi, T.; Yamamoto, M.; Hiraoka, Y. Meiosis-Specific Noncoding RNA Mediates Robust Pairing of Homologous Chromosomes in Meiosis. Science 2012, 336, 732-736. [CrossRef]

137. Hacisuleyman, E.; Goff, L.; Trapnell, C.; Williams, A.; Henao-Mejia, J.; Sun, L.; McClanahan, P.; Hendrickson, D.G.; Sauvageau, M.; Kelley, D.R.; et al. Topological organization of multichromosomal regions by the long intergenic noncoding RNA Firre. Nat. Struct. Mol. Biol. 2014, 21, 198-206. [CrossRef] [PubMed]

138. Minajigi, A.; Froberg, J.; Wei, C.; Sunwoo, H.; Kesner, B.; Colognori, D.; Lessing, D.; Payer, B.; Boukhali, M.; Haas, W.; et al. Chromosomes. A comprehensive Xist interactome reveals cohesin repulsion and an RNA-directed chromosome conformation. Science 2015, 349, 282-294. [CrossRef] [PubMed]

139. Fang, H.; Bonora, G.; Lewandowski, J.P.; Thakur, J.; Filippova, G.N.; Henikoff, S.; Shendure, J.; Duan, Z.; Rinn, J.L.; Deng, X.; et al. Trans- and cis-acting effects of Firre on epigenetic features of the inactive $X$ chromosome. Nat. Commun. 2020, 11, 6053. [CrossRef]

140. Thakur, J.; Henikoff, S. Architectural RNA in chromatin organization. Biochem. Soc. Trans. 2020, 48, 1967-1978. [CrossRef]

141. Creamer, K.M.; Kolpa, H.J.; Lawrence, J.B. Nascent RNA scaffolds contribute to chromosome territory architecture and counter chromatin compaction. Mol. Cell 2021, 81, 3509-3525.e5. [CrossRef]

142. Ding, D.-Q.; Okamasa, K.; Katou, Y.; Oya, E.; Nakayama, J.-I.; Chikashige, Y.; Shirahige, K.; Haraguchi, T.; Hiraoka, Y. Chromosome-associated RNA-protein complexes promote pairing of homologous chromosomes during meiosis in Schizosaccharomyces pombe. Nat. Commun. 2019, 10, 5598. [CrossRef]

143. Yamashita, A.; Watanabe, Y.; Nukina, N.; Yamamoto, M. RNA-Assisted Nuclear Transport of the Meiotic Regulator Mei2p in Fission Yeast. Cell 1998, 95, 115-123. [CrossRef]

144. Shimada, T.; Yamashita, A.; Yamamoto, M. The Fission Yeast Meiotic Regulator Mei2p Forms a Dot Structure in the Horse-Tail Nucleus in Association with thesme2Locus on Chromosome II. Mol. Biol. Cell 2003, 14, 2461-2469. [CrossRef] [PubMed]

145. Galupa, R.; Heard, E. X-Chromosome Inactivation: A Crossroads Between Chromosome Architecture and Gene Regulation. Annu. Rev. Genet. 2018, 52, 535-566. [CrossRef] [PubMed]

146. Patrat, C.; Ouimette, J.-F.; Rougeulle, C. X chromosome inactivation in human development. Development 2020, 147 , dev183095. [CrossRef] [PubMed]

147. Jeon, Y.; Lee, J.T. YY1 Tethers Xist RNA to the Inactive X Nucleation Center. Cell 2011, 146, 119-133. [CrossRef]

148. Wang, J.; Mager, J.; Chen, Y.; Schneider, E.; Cross, J.; Nagy, A.; Magnuson, T. Imprinted X inactivation maintained by a mouse Polycomb group gene. Nat. Genet. 2001, 28, 371-375. [CrossRef]

149. Dixon-McDougall, T.; Brown, C.J. Independent domains for recruitment of PRC1 and PRC2 by human XIST. PLoS Genet. 2021, 17, e1009123. [CrossRef] 
150. Yang, F.; Deng, X.; Ma, W.; Berletch, J.B.; Rabaia, N.; Wei, G.; Moore, J.M.; Filippova, G.N.; Xu, J.; Liu, Y.; et al. The lncRNA Firre anchors the inactive $X$ chromosome to the nucleolus by binding CTCF and maintains H3K27me3 methylation. Genome Biol. 2015, 16, 52. [CrossRef]

151. Rinn, J.; Guttman, M. RNA and dynamic nuclear organization. Science 2014, 345, 1240-1241. [CrossRef]

152. Poleshko, A.; Smith, C.L.; Nguyen, S.C.; Sivaramakrishnan, P.; Wong, K.G.; Murray, J.I.; Lakadamyali, M.; Joyce, E.F.; Jain, R.; Epstein, J.A. H3K9me2 orchestrates inheritance of spatial positioning of peripheral heterochromatin through mitosis. eLife 2019, 8, e49278. [CrossRef] [PubMed] 